\title{
The Development of Rural Sustainability Using Participatory Action Research: A Case Study from Guatemala
}

\author{
Faye Anderson \\ Texas A \& M AgriLife Research Center, Beaumont, Texas, USA \\ Email: andersonfaye7@gmail.com
}

Received 18 February 2015; accepted 11 March 2015; published 12 March 2015

Copyright (c) 2015 by author and Scientific Research Publishing Inc.

This work is licensed under the Creative Commons Attribution International License (CC BY). http://creativecommons.org/licenses/by/4.0/

(c) (i) Open Access

\section{Abstract}

Rural sustainability, although ambiguous at times, is an evolving science on the right way to higher shared value. Despite the rising demand for sustainability, its parameterization is still underdevelopment and differs spatiotemporally. This is a case study of developing rural sustainability using participatory action research (PAR) in small farms in the southern tropical Pacific coast of the Departments of Retalhuleu and Suchitepequez in Guatemala. This study covers five years (20102014) of communities' involvement in open dialogue, field research and project leadership. The data were collected through multi-dimensional approach including hands-on training, surveys with farmers and their families, and public conferences. Exploratory statistical analyses showed that the differences in the responses collected were statistically significant. In addition, the responses on average reflect gratification from the local communities. This validates the positive change of these intervention programs that are both relevant and science-based. The application of PAR in these communities has proved to successfully allow for a two-way learning process between locals and field experts, improve the livelihood and thus sustainability of their lives, and empower them to take initiative with problem-solving actions.

\section{Keywords}

Agricultural Sustainability, Rural Sustainability, Community Survey, Lowland Guatemala, Participatory Action Research

\section{Introduction}

Sustainability can be defined as balancing equity, profit and the environment or achieving the triple bottom lines

How to cite this paper: Anderson, F. (2015) The Development of Rural Sustainability Using Participatory Action Research: A Case Study from Guatemala. Journal of Human Resource and Sustainability Studies, 3, 28-33. 
(TBL) of people, profit and planet [1]. Farmers, as agroecosystem managers, have different definitions for sustainability according to their work context and the national and international context. Sustainability meaning is not the same within one location nor is constant over time [2]. Despite the existence of some similarities among definitions of sustainability, there are big gaps among them. However, since the concept is clear and agreedupon, the definition can be broadened to include all activities, services and products in the direction of environmentally friendly and socially advancing farming operations. This means that a farm has health, social, and environmental responsibilities in addition to its financial ones. These responsibilities are necessary for the farm's long-term successful existence [3]. Some farms have prioritized their social and sustainability responsibilities to their short-term profits. The success of these agroecosystems due to their popularity has driven other larger ones to follow their steps [4]. Studying both two examples of sustainable farms, a large one and a smaller one, can be committed to social and environmental sustainability but in their own different ways. Triple Bottom Line (TBL) accounting continues to be a popular accounting management style because it assesses a system's success not only by the financial bottom line but also by its social and environmental impacts. Although sustainability is a noble old concept, it brings more issues that farmers need to address in order to be able to implement it. The main issue is balancing the three bottom lines of the society needs, profitability, and the environment.

The purpose of this study is to investigate a case study of developing sustainability in rural Guatemala using participatory action research. This is a multi-dimensional approach that allows for interaction between field experts and farmers and their families where information is gathered through interviews, hands-on workshops and community conferences. PAR methodologically closes the gap between theory and application especially in the field of socioecological intervention [5]. Its strength lies in the involvement of people themselves in leading projects that positively change their lives and their communities through collective creativity, where scientific advances are customized and implemented in a manner that allows for reflection on causalities and outcomes. Reflection on the developments made in these communities not only improves the lives of farmers and their families in these rural areas, but also empowers their potential to resolve future issues. Similar to most PAR applications, this study captures the simultaneous relevancy of measures used, involvement of participants and establishing a new baseline where the search for a new problem is established [6].

\section{Methods}

\subsection{Location and Time}

Retalhuleu and Suchitepequez are two rural municipalities of the twenty two departments of Guatemala (Figure 1). These locations symbolize rural Guatemala in terms of high literacy rate especially among females, children malnutrition and infant mortality, persistently poor population and degraded lands [7] [8]. This has led to the evolvement of non-profit organizations that develop and implement farming sustainability plans in an effort to break the poverty cycle in those regions. The study covers the participatory action research conducted from 2010 through 2014.

\subsection{Participatory Action Research Methods}

The key activities that were used can be categorized under three phases: research, education and action [9]. These phases are summarized in Table 1. The agronomic measures that were introduced to farmers included no till farming, soil analysis, no burn crop residue, pigeon pea and quality protein maize (QPM) as cover crops [10], use of green manure, and education on deforestation and water resource management. These measures were introduced after thoroughly studying the potential of the land and the society, with the help of local and worldwide research organizations. Moreover, two community reach programs were introduced to help farmers reach to other farmers; and mothers or neighbors reach to each other with new knowledge about health benefits of consumption of chaya, QPM, and pigeon pea. An annual comprehensive survey has been conducted since 2013 to measure the community's sustainable needs.

\subsection{Statistical Testing}

To test for homogeneity of variances and means between the years' sustainability indicators values Fisher's Ftest and repeated measures t-test were conducted respectively. Both were performed at the significance level of 0.05 . R software was used for the statistical analyses [12]. 
Table 1. Activities of participatory action research.

\begin{tabular}{cc}
\hline Phase & Activity \\
\hline Research & Partner with local and international researchers to find solutions to improve soil quality, increase crop yield, diversify \\
crop, improve health and increase knowledge
\end{tabular}

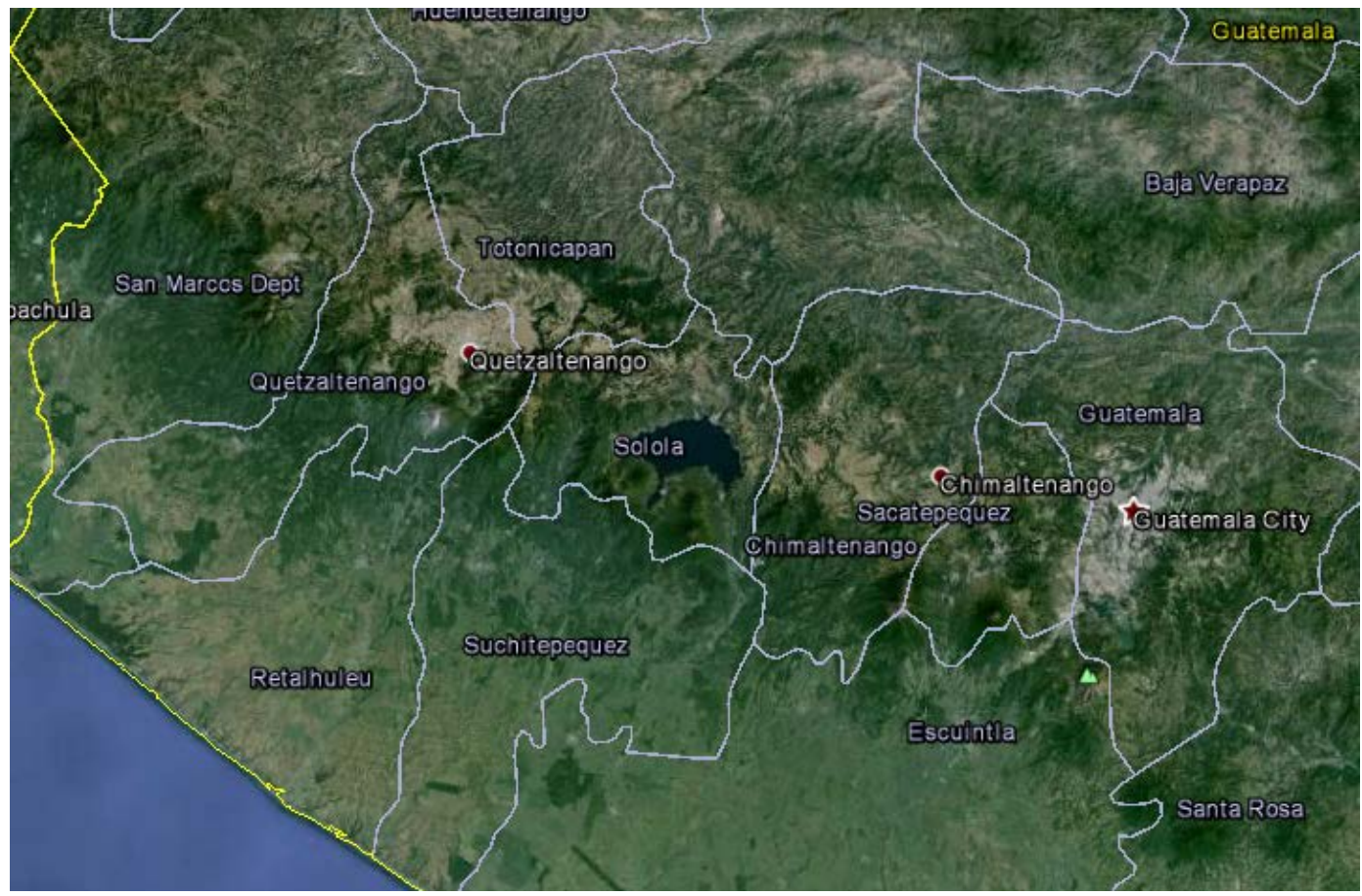

Figure 1. Retalhuleu and Suchitepequez Municipalities on the Pacific side of Guatemala [11].

\section{Results}

Figure 2 presents the number of communities and farmers who participated in the programs in each year. Despite the slow increase in numbers in the early years, the fifth years' (2014) number of farmers is four times that of the first year (2010) and the number of communities supported increased by a factor of 500\% [13]-[15]. These progressions indicate the increased local trust in the applied measures despite the early reluctance to change the habitual measures like burning crop residues and using chemical fertilizers. This gradual trust was achieved through the positive impacts that supported farmers have observed by implementing test parcel technique where a small area of the farm is dedicated to the new agronomic measures and its results are compared to the control area. Fisher's F-tests and repeated measures t-tests p-values were all less than the significance level. That is, we reject the null hypotheses of equal variances and means respectively. This means that the differences between the responses across years are distinct from each other, which is an evidence of significant change across the years.

The main outcomes of the first two years (2010-2011) consisted of training the participating communities on how to scientifically experiment in the field by dedicating a parcel of the land to conservation tillage, green manures, agroforestry and new crop (pigeonpea), establishing leadership groups of the community who take initiative in establishing innovative sustainability measures, and developing multi-dimensional means of sharing and exchanging knowledge in the area through two national conferences. Pigeonpea was introduced for many rea- 


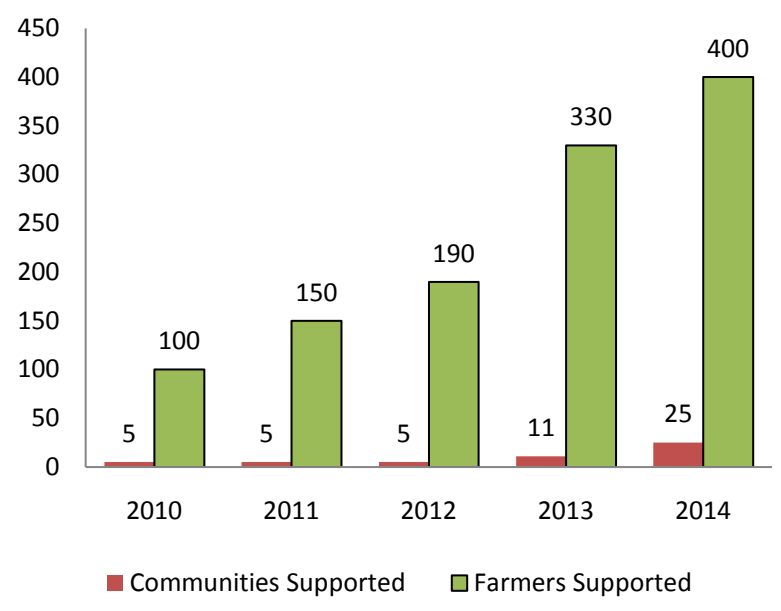

Figure 2. Number of communities and farmers supported by the organization (2010-2014).

sons. It is "drought-resistant bean bred to grow in the dry-season with nearly no input. It cuts fertilizer costs by fixing organic nitrogen, decreasing soil compaction and erosion and providing high protein and nutrient rich food" [13]. The introduction of pigeonpea has been accompanied by workshops especially for women to teach them new ways to benefit from pigeonpea as a local alternative to black bean. This measure had a great sustainable value to the locals on the three bottom lines of people, planet, and profit since it enabled the farmers to buy back over 2000 pounds of seeds.

The next year (2012) continued with the programs started at the beginning of the organization's mission but added Farmer-to-Farmer program. This is a community leadership program that trains locals in sustainable measures like food and nutritional security. Moreover, another community leadership program was piloted to teach women cooking methods and the health benefits of the newly introduced crop. During that year 30 women were trained and encouraged to teach their neighbors and friends what they learned, increasing the leaderfulness of the community [16]. In the fourth year (2013) and in the midst of drought conditions, the farmers' experimental parcels increased their corn yield by $\$ 180$, which is the cost of one year's schooling of one child. This increased the locals' trust in the intervention program and grew their interest to attempt conservation agriculture trials with sesame, the second most central crop of the region. Moreover, more pigeonpea varieties were introduced and welcomed by the farmers because of their health benefits as well as their potential to triple the crop's yield. In that same year, $40 \%$ of the farmers stopped using chemical fertilizers, which increased the crop yield by $25 \%$. This increase in income not only affects the profitability sustainability dimension but also the social aspect since it translates in higher purchase power and more access to health and wellbeing means. Another achievement in 2013 was the planting of 6000 new Chaya trees with local families, which provide easily accessible local food that is of high protein content [13].

Starting from the year 2013, a detailed community survey has been conducted in order to have better understanding of the community needs as well as to assess the performance of the introduced programs. This milestone is an evidence of how knowledge transfer has moved from both ways in order to adjust the path of the programs [14]. By the last year of this study (2014), more progress has been made in terms of testing the success of the interventions introduced during the previous years. Figure 3 presents the main responses collected community survey, highlighting the enormous accomplishments that the locals have managed to achieve [15].

Figure 4 highlights the major needs of the locals and their general satisfaction with the on-going programs. The majority of farmers believe that the soil quality has improved due to no burn crop residue, no-till, adding pigeonpea as a cover crop, and using green manures. The $22 \%$ who believe that the soil quality has declined in the last five years attributed the decline to erosion and over application of chemical fertilizers in the past. Of the challenges that face the local farmers is access to low cost green manures and high quality seeds. Another problem is how to measure soil quality without having to pay high fees for soil analysis tests. The soil of these communities is mainly of haplic vertisol and pellic vertisol, which have heavy clay content with the main issue of being difficult to work in either during dry or wet conditions. This results in cultivation challenges especially 


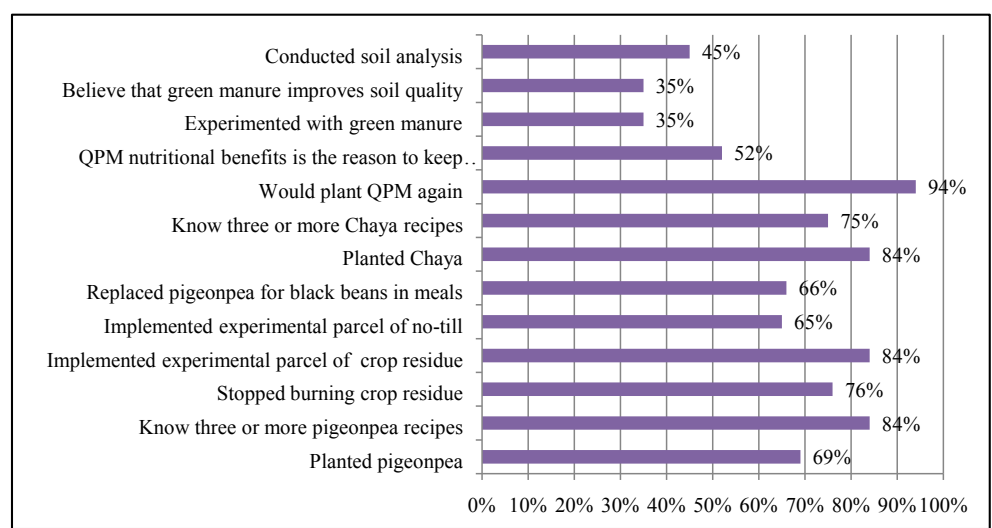

Figure 3. The main outcomes of 2014 community survey [15].

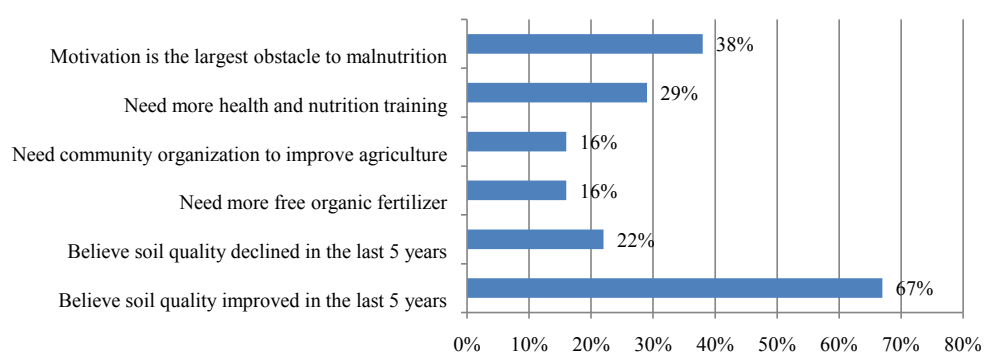

Figure 4. Overall satisfaction with the programs and future requirements [16].

between extremely dry or extremely wet conditions, which directly affect crop yield and profitability. Some of the measures that need further investigation and have the potential of increasing crop yield and decreasing soil erosion for that region include surface drainage, seedbed preparation, and development of water catchments [17]. Increasing the crop yield while enhancing the soil quality synchronously can be the bottleneck achievement for that region.

\section{Discussion}

This case study showcases the successful application of the seven aspects of PAR [18] [19]: participatory, recognizes the rural communities in Guatemala as a unit of identity, engaging both practitioners (farmers) and researchers (field experts), provides a two-way learning process for the community and its members, develops a systematic method of building the local community capacity, empowering locals in order to raise control over their livelihood by promoting community strength and problem-solving skills, and a measure of harmonizing rigorous research with relevant action.

One of the limitations of this research is lack of official surveys prior to the years of study, which is customary for rural poor regions in the Country and the Region in general. Such surveys would have established a baseline to compare the annual achievements against. Moreover, it would have identified the amount of prior knowledge that the farmers and their families had about sustainable practices, which can bring together the local and the rigorous scientific knowledge towards developing sustainable practices that are relevant and applicable. However, the statistical significances found in the data collected point to significant transformations due to the developments introduced. Also, despite the perceived participatory advantage of PAR over conventional development methods, its application in rural regions is challenging because of local resistance and natural distrust of outside non-indigenous resources. This calls for extending the time required for the development and implementation of such out reaching programs. In addition, despite the many similarities between these neighboring communities, each has its own specific needs that might need some customization of the program in order to align the sustainable livelihood of these groups. Another challenge that faces the development of agricultural sustainability is the increasing rate of rural pluriactivity and the farmers' interest to pursue better less-challenging sources of income. Finally, the most critical challenge is the need for empowerment in a timely fashion in 
order to attain the autonomy of farmers and their families.

\section{Conclusion}

Ongoing adjustments of the plans are recommended to continue in order to keep the locals' high engagement and ownership of the programs. Nevertheless, the high two-way participation by farmers and their families in the programs indicates the success of PAR in those communities where new knowledge has been developed that is relevant to the farming practices and environmental conditions of the region. Collective analysis has identified power persons in the communities who are integrated as change agents or promoters.

\section{References}

[1] Dhiman, S. (2008) Products, People, and Planet: The Triple Bottom Line Sustainability Imperative. Journal of Global Business Issues, 2, 51-57.

[2] Freeman, I. and Hasnaoui, A. (2011) The Meaning of Corporate Social Responsibility: The Vision of Four Nations. Journal of Business Ethics, 100, 419-443. http://dx.doi.org/10.1007/s10551-010-0688-6

[3] Schwab, K. (2008) Global Corporate Citizenship: Working with Governments and Civil Society. Foreign Affairs, 87, 107-118.

[4] Smith, M. (1994) The Real Dirt: Farmers Tell about Organic and Low-Input Practices in the Northeast. Northeast Organic Farmers Association.

[5] Villasante, T.R. (2006) Desbordes creativos. Estilos y estrategias para la transformaciónsocial. Los libros de la Catarata, Madrid.

[6] Cuéllar, M. and Calle, A. (2011) Can We Find Solutions with People? Participatory Action Research with Small Organic Producers in Andalusia. Journal of Rural Studies, 27, 372-383. http://dx.doi.org/10.1016/i.jrurstud.2011.08.004

[7] UNESCO (2012) Integral Family Literacy: Guatemala. http://www.unesco.org/uil/litbase/?menu=16\&programme=94

[8] World Bank (2013) Guatemala: en 44\% de los municipios rurales, tres de cada cuatro personas viven en pobreza. http://www.bancomundial.org/es/news/press-release/2013/04/30/mapa-de-pobreza

[9] Balcazar, F.E. (2003) Participatory Action Research (PAR): Conceptual and Implementation Difficulties. Fundamentals Humanities. Year IV - No. I / II No. 7-8, 59-77.

[10] Lu, Y.C., Watkins, K.B., Teasdale, J.R. and Abdul-Baki, A.A. (2000) Cover Crops in Sustainable Food Production. Food Reviews International, 16, 121-157. http://dx.doi.org/10.1081/FRI-100100285

[11] Google Earth (2014) Retalhuleu and Suchitepequez Municipalities, Guatemala.

[12] R Development Core Team (2014) R: A Language and Environment for Statistical Computing. R Foundation for Statistical Computing, Vienna.

[13] Semilla Nueva (2012) Annual Report 2011-2012.

[14] Semilla Nueva (2013) Annual Report 2013.

[15] Semilla Nueva (2014) Community Survey 2014 - Summary of Results.

[16] Tannenbaum, R. and Schmidt, W.H. (1958) How to Choose a Leadership Pattern. Harvard Business Review, 36, 95101.

[17] Gauggel, C. (2012) Satus and Needs of Soil Management in Central America. http://www.fao.org/fileadmin/user_upload/GSP/docs/WS_managinglivingsoils/Gauggel_CentralAmerica.pdf

[18] Israel, B., Schultz, A., Parker, E. and Becker, A. (1998) Review of Community-Based Research: Assessing Partnership Approaches to Improve Public Health. Annual Review of Public Health, 19, 173-202. http://dx.doi.org/10.1146/annurev.publhealth.19.1.173

[19] Margoluis, R. and Salafsky, N. (1998) Measures of Success: Designing, Managing and Monitoring Conservation and Development Projects. Island Press, Washington DC. 